\title{
PERAN SELF-ESTEEM DAN SELF-FORGIVENESS SEBAGAI PREDIKTOR SUBJECTIVE WELL-BEING PADA PEREMPUAN DEWASA MUDA
}

\author{
Nadya Puspita Ekawardhani', Samsunuwiyati Mar'at ${ }^{2}$, Riana Sahrani ${ }^{3}$ \\ ${ }^{1}$ Fakultas Psikologi, Universitas Tarumanagara, Jakarta \\ Email: nadyapuspitaa@gmail.com \\ ${ }^{2}$ Fakultas Psikologi, Universitas Tarumanagara, Jakarta \\ Email: samsunuwiyatimarat@yahoo.com \\ ${ }^{3}$ Fakultas Psikologi, Universitas Tarumanagara, Jakarta \\ Email: rianas@fpsi.untar.ac.id
}

Masuk :15-04-2019, revisi: 10-09-2019, diterima untuk diterbitkan : 10-09-2019

\begin{abstract}
ABSTRAK
Subjective well-being (SWB) merupakan gambaran kebahagiaan, kepuasaan hidup, dan gambaran afek positif-negatif individu. Self-esteem (penghargaan diri) dan self-forgiveness (penerimaan diri) merupakan dasar penilaian positif individu terhadap dirinya. Oleh sebab itu, penelitian ini dilakukan guna memperoleh peran self-esteem dan selfforgiveness sebagai prediktor SWB pada perempuan dewasa muda. Penelitian ini menggunakan tiga alat ukur, yakni Rosenberg Self-Esteem Scale (RSES), Heartland Forgiveness Scale (HFS), dan Oxford Happiness Questionnaire (OHQ). Penelitian ini juga hendak melihat seberapa besar peranan self-esteem dan self-forgiveness terhadap SWB. Penelitian ini merupakan penelitian kuantitatif dengan teknik non-probability sampling. Subjek dalam penelitian ini berjumlah 500 perempuan yang berusia 20 - 28 tahun, memiliki minimal pendidikan SMA/ sederajat, dan berdomisili di Jabodetabek. Seluruh data diolah dengan statistic deskriptif dan analis regresi berganda menggunakan SPSS Statistic versi 24. Penelitian ini menunjukkan bahwa self-esteem dan self-forgiveness berperan secara signifikan sebagai prediktor SWB pada perempuan dewasa muda, yakni sebasar 53,8\%. Berdasarkan besaran peran, self-esteem memiliki peran sebagai prediktor yang lebih besar dari self-forgiveness, yakni sebesar 52,5\%. Sedangkan, selfforgiveness memiliki peran sebesar $17,9 \%$. Bagi penelitian selanjutnya, jumlah partisipan dapat dikontrol secara merata agar memperoleh hasil yang lebih baik. Selain itu, dapat pula dilakukan intervensi pada partisipan yang memiliki self-esteem, self-forgiveness dan SWB yang cenderung rendah, sehingga peneliti dapat mengontrol dan melakukan follow-up. Penelitian selanjutnya juga dapat menguji forgiveness of others dan forgiveness of the situation, untuk melihat seberapa besar peran keduanya terhadap SWB. Meneliti pada rentang usia dewasa dewasa muda tengah (28 - 33 tahun) dan dewasa muda akhir (33 - 40 tahun) juga dapat diaplikasikan pada penelitian selanjutnya.
\end{abstract}

Kata Kunci: self-esteem, self-forgiveness, subjective well-being, dan perempuan dewasa muda.

\section{ABSTRACT}

Subjective well-being (SWB) is an image of happiness, life satisfaction, and an image of the individual's positive and negative affects. Self-esteem and self-forgiveness are the basis for an individual's positive assessment of him/herself. Therefore, this study was conducted to obtain the role of self-esteem and self-forgiveness as predictors of SWB in young adult women. This study used three measuring instruments, namely Rosenberg Self-Esteem Scale (RSES), Heartland Forgiveness Scale (HFS), and Oxford Happiness Questionnaire (OHQ). This study also aims to discover the role of self-esteem and self-forgiveness towards SWB. This research is a quantitative study with non-probability sampling technique. Subjects in this study were 500 women aged 20-28 years, with minimum of high school / equivalent education level, and lived in Jabodetabek area. The data was processed by exploring (descriptive statistics) and analyzing (regression) techniques using SPSS Statistics version 24. This study shows that self-esteem and selfforgiveness play a significant role as predictors of SWB in young adult women, which is $53.8 \%$. Based on the magnitude of the role, self-esteem is a greater predictor of SWB than self-forgiveness, equal to $52.5 \%$ with selfforgiveness equal to $17.9 \%$. For further research, the number of participants can be made more even in order to obtain better results. In addition, intervention can also be conducted on participants with low self-esteem, selfforgiveness and SWB, so that researchers can conduct control and follow-up. Future studies may also examine forgiveness of others and forgiveness of the situation, in order to find out their contribution towards SWB. Research on middle young adults(28-33 years old) and late young adults (33-40 years) can also be applied in subsequent studies

Keywords: self-esteem, self-forgiveness, subjective well-being, and young adult women. 


\section{PENDAHULUAN \\ Latar Belakang}

Subjective well-being merupakan evaluasi subjektif seseorang mengenai kehidupan, seperti kepuasan hidup, kepuasan pernikahan, kepuasan pekerjaan, emosi menyenangkan, serta merupakan evaluasi kognitif dan afektif seseorang tentang hidupnya. Evaluasi ini meliputi penilaian emosional terhadap berbagai kejadian yang dialami yang sejalan dengan penilaian kognitif terhadap kepuasan dan pemenuhan kebutuhan (Diener, Oishi, \& Tay, 2018). Selain itu, Veenhouven (dalam Diener et al, 2018) menjelaskan bahwa subjective well-being merupakan penilaian seseorang dalam melihat kualitas kehidupannya sesuai harapannya dan gambaran seseorang dalam kemampuannya merasakan emosi-emosi yang menyenangkan. Sehingga, dapat dikatakan subjective well-being merupakan penilaian secara subjektif terhadap apa yang dimiliki dan dihadapi oleh individu.

Berdasarkan teori subjective well-being yang dikemukakan oleh Diener, et al (2018), peneliti mencari fenomena di sekeliling peneliti, yakni di wilayah Jabodetabek, yang berkaitan dengan penilaian subjektif individu terhadap dirinya. Peneliti menemukan masalah yang beragam pada empat perempuan dewasa muda (SA, VA, CJ, dan AP) di wilayah Jabodetabek. Mereka mengaku memiliki masalah emosional. SA merasa dirinya jelek, tidak berharga, dan merasa tidak ada yang dapat dibanggakan dari dirinya. SA mencari kepuasan diri melalui perilaku memuntahkan makanan dengan memasukan jari ke dalam tenggorokannya hingga luka. Namun, ia tidak pernah puas dan merasa depresi akibat tidak mampu berhenti dari kebiasaanya. VA merasa dirinya kurang baik, tidak mampu menunjukkan kemampuannya, dan terus merasa tidak puas dengan pencapaian yang ia raih, meskipun VA sendiri yang menetapkan target pencapaiannya. Setiap menghadapi kegagalan, VA merasakan kecemasan dan kepanikan berlebih. Oleh sebab itu, VA terus menetapkan standar pencapaian yang tinggi terhadap dirinya, hingga membuat dirinya menjadi seorang workaholic dan mengalami insomnia. CJ mengaku kurang percaya diri, sering berfikir negatif, dan sulit percaya dengan orang lain. Hal tersebut membuat CJ cenderung menarik diri dari lingkungan, meskipun sebenarnya CJ merasa tidak nyaman dengan perilakunya. AP merasa diri tidak berharga, tidak percaya diri, dan merasa keberadaan dirinya tidak akan berpengaruh terhadap orang lain. Perasaan tersebut membuat AP melakukan self-harm dan AP juga pernah memiliki pikiran untuk bunuh diri.

Hasil wawancara tersebut menjadi dasar pemikiran peneliti mengenai bahaya yang akan timbul apabila masalah emosional tersebut tidak cepat ditangani. Peneliti menemukan fenomena dampak dari masalah emosional di Indonesia. Berdasarkan data perkiraan WHO (dalam Riset Kesehatan Dasar, 2013), angka kematian akibat bunuh diri pada tahun 2012 mencapai 10.000 kasus. Jumlah kasus tersebut merupakan sebuah peningkatan dibandingkan dengan jumlah kematian akibat bunuh diri di Indonesia pada tahun 2010, yakni sebesar 5.000 kasus. Peningkatan tersebut dapat dipastikan bahwa semakin tinggi tuntutan hidup individu, maka kemungkinan individu mengalami depresi pun meningkat. Ronny T. Wirasto, seorang Psikiater, mengungkapkan ada sebanyak 100.000 orang di Jakarta yang pernah mencoba untuk bunuh diri pada tahun 2006. Jika dirata-ratakan, setiap harinya ada sekitar 274 orang di ibu kota yang melakukan percobaan bunuh diri pada tahun itu. Selain itu, Ronny juga menemukan sebagian besar percobaan bunuh diri disebabkan oleh masalah sosial dan ekonomi (Wirasto, 2012).

Pada tahun 2013, Riset Kesehatan Dasar (Riskesdas) dari Kementrian Kesehatan (Kemenkes) Republik Indonesia memperoleh prevalensi masyarakat berusia 15 tahun ke atas yang mengalami masalah emosional. Prevalensi tersebut mencapai 6\% atau sekitar 14 juta masyarakat dari seluruh jumlah penduduk Indonesia yang berjumlah sekitar 252 juta masyarakat pada tahun 2013. Masalah emosional tersebut ditunjukkan dengan gejala-gejala depresi dan kecemasan (Riset Kesehatan Dasar, 2013). Sedangkan, data WHO pada tahun 2016 (dalam Kementrian Kesehatan RI, 2017) menunjukkan bahwa terdapat sekitar 35 juta masyarakat Indonesia dari jumlah keseluruhan sekitar 261,1 juta, mengalami depresi. Peneliti juga menemukan fenomena secara global. Berdasarkan hasil riset World Health Organization (WHO), ditemukan bahwa pada umumnya masalah kesehatan mental yang terjadi adalah kecemasan dan depresi. Diperkirakan 4,4\% dari populasi global mengalami depresi dan 3,6\% dari populasi global mengalami kecemasan. Jumlah masyarakat yang mengalami depresi meningkat lebih dari 18\% antara tahun 2005 sampai 2015. Depresi merupakan penyebab terbesar masalah kesehatan mental di seluruh dunia. Lebih dari 
$80 \%$, depresi dialami masyarakat yang tinggal di negara berpenghasilan rendah dan menengah (WHO, 2017).

Penelitian Erol dan Orth (2011) yang menyatakan bahwa antisocial behavior, eating disturbances, depression, dan suicidal ideation mengacu pada low self-esteem, mendukung hasil wawancara keempat perempuan dewasa muda. Keempatnya juga mengaku masalah emosional yang mereka alami mempengaruhi kebahagiaan mereka. Kurangnya keyakinan terhadap diri dan kurangnya pandangan positif terhadap diri dapat mendorong individu mengalami masalah emosional yang mengacu pada masalah kesehatan mental. Keyakinan diri dan pandangan positif terhadap diri merupakan dasar dari pola pikir individu terhadap keberhargaan diri (self-esteem) dan penerimaan diri (self-forgiveness). Asumsi tersebut didasari oleh pengertian self-forgiveness yang merupakan kemampuan seseorang dalam mengabaikan rasa benci akan diri sendiri, dan kemampuan membangun rasa cinta terhadap diri. Kemampuan tersebut ditandai dengan sikap positif terhadap keberadaan diri dengan tidak menghukum diri sendiri (Carpenter, et al., 2016). Selain itu, self-esteem menurut National Association for Mental Health (2016) mengarah pada keyakinan diri, bagaimana individu memandang dirinya, kemampuan apa yang dimiliki dirinya, dan berbagai hal positif dan negatif mengenai dirinya dan harapan di masa depan. Rosenberg (1965), dalam Abdel-Khalek (2016) juga mengungkapkan bahwa self-esteem adalah penilaian umum tentang diri sendiri yang berkaitan dengan kemampuan diri, memiliki sesuatu yang bernilai, dan memiliki nilai dalam pandangan orang lain.

Berbagai hasil penelitian mengenai perempuan dewasa juga dapat mendukung hasil wawancara dengan keempat perempuan dewasa muda, yang menemukan bahwa perempuan dewasa muda (usia 20 - 40 tahun) cenderung memiliki low self-esteem dan cenderung meningkat saat memasuki usia dewasa madya (usia 40 - 60 tahun) (Robins et al., 2002; Galambos et al., 2006, dalam Devi \& Jyotsana, 2018). Selain itu, pada penelitian Erol dan Orth (2011) mengenai perbedaan gender, juga ditemukan bahwa baik pada masa remaja maupun dewasa, laki-laki memiliki self-esteem yang lebih tinggi dibandingkan perempuan. Masa perkembangan dewasa merupakan masa di mana individu mulai menjalani tanggung jawab kehidupan yang lebih kompleks. Individu dituntut untuk mampu menghadapi tantangan dan rintangan, baik dalam pendidikan, pekerjaan, maupun dalam menjalani peran sosial. Individu mulai ditempatkan pada kondisi bahwa dirinya tidak lagi bergantung pada orang tua atau orang yang menanggung kehidupannya. Dengan kata lain, individu dituntut untuk mampu bertindak mandiri. Berbagai tantangan dan tuntutan tersebut dapat menjadi tekanan bagi individu dewasa muda, dan masing-masing dari mereka menghadapi dan menerima tekanan tersebut dengan cara dan hasil yang berbeda-beda. Individu dapat menerima tekanan tersebut dengan positif, seperti berani menghadapi berbagai hal baru dan kesulitan-kesulitan di dalamnya, serta mampu melihat kegagalan sebagai pembelajaran untuk mengembangkan kelebihan yang dimiliki. Sebaliknya, individu yang menerima tekanan sebagai hal negatif dapat melihat dirinya tidak berharga atau tidak memiliki keahlian, dan mudah untuk merasa putus asa saat menghadapi kegagalan. Asumsi tersebut dapat menjadi dasar bahwa kesehatan fisik dan mental merupakan kunci penting dalam keberhasilan menghadapi tantangan di masa perkembangan dewasa.

Self-esteem erat kaitannya dengan forgiveness, terutama self-forgiveness. Individu yang mampu menghargai dirinya sendiri dan bersyukur atas apa yang dimilikinya, cenderung akan mengarahkan individu pada penerimaan diri (self-forgiveness) sampai pada kekurangan dan kegagalannya. Asumsi tersebut sejalan dengan definisi dari self-forgiveness sendiri, yaitu kemampuan seseorang dalam mengabaikan rasa benci akan diri sendiri setelah berbuat kesalahan, dan membangun rasa cinta terhadap diri (Carpenter et al., 2016). Individu mampu mengaplikasikan self-forgiveness saat ia sadar bahwa manusia tidak sempurna dan ketidak-sempurnaan tersebut yang dapat menjadi dasar manusia tidak selamanya mampu mencapai ideal self. Self-forgiveness dapat diaplikasikan saat individu mampu mensykuri kekurangnya seperti ia mensyukuri kelebihannya (Jacinto \& Edwards, 2011). Kemampuan tersebut ditandai dengan sikap positif terhadap kesalahan dengan tidak menghukum diri sendiri. Sehingga, dapat dikatakan bahwa individu yang mampu menerima diri seutuhnya merupakan individu yang cenderung memiliki high self-esteem, karena ia mampu memaklumi dan mensyukuri kekurangan dirinya. Sebaliknya, individu dengan low self-esteem akan sulit menoleransi kekurangan diri dan cenderung membenci dirinya. Penerimaan dan pemaafan diri tersebut dapat menjadi dasar pemikiran bahwa individu dapat memiliki kehidupan yang lebih bahagia atau dengan 
kata lain memiliki subjective well-being yang positif. Sebaliknya, individu yang sulit menerima dirinya cenderung memiliki low self-esteem dan akan mengarah pada subjective well-being yang rendah. Asumsi tersebut juga didasari oleh fenomena yang peneliti dapatkan dari keempat perempuan dewasa muda yang berdomisili di Jabodetabek. Keempat perempuan yang peneliti wawancara cenderung memiliki low selfesteem, karena mereka cenderung memandang dirinya tidak berharga dan sulit merasa puas akan apa yang telah mereka capai. Kecenderungan low self-esteem tersebut mengarahkan mereka kepada minimnya kepuasan dan kebahagiaan hidup. Saat terdapat pencapaian yang mereka dapatkan, mereka tidak memandang hal tersebut sebagai sesuatu yang patut dibanggakan dan disyukuri. Selain itu, mereka juga mengalami kesulitan dalam mencoba hal baru atau menyelesaikan suatu persoalan.

Hal tersebut dapat menjadi contoh bahwa individu dengan low self-esteem akan mengalami kesulitan dalam menjalani kehidupan yang diinginkannya yang mengacu pada rasa frustasi dan depresi. Saat individu mengalami kesulitan dalam mengatasi persoalan hidupnya yang disebabkan oleh low self-esteem, hal tersebut dapat mengarah pada sikap menarik diri dari lingkungan sosial. Sikap tersebut dapat menjadi akar penyebab gangguan emosional yang berkaitan dengan subjective well-being individu. Oleh sebab itu, topik mengenai self-esteem dan self-forgivenes penting untuk diteliti dan diulas, karena self-esteem dan selfforgiveness berkaitan erat dengan kesehatan, khususnya kesehatan mental. Penelitian ini akan lebih fokus terhadap diri individu yang bersangkutan secara global, sehingga peneliti menggunakan self-esteem dan self-forgiveness sebagai prediktor penelitian. Prediktor tersebut berperan sebagai bukti bagaimana gambaran subjective well-being perempuan dewasa muda, khususnya di wilayah Jabodetabek. Wilayah tersebut peneliti asumsikan sebagai wilayah tempat tinggal yang paling memiliki potensi dalam persaingan dan pengakuan sosial di jaman milenial saat ini, sehingga di wilayah tersebut terdapat berbagai tekanan hidup yang perlu dihadapi oleh masyarakat.

\section{Rumusan Masalah}

Apakah self-esteem dan self-forgiveness berperan sebagai prediktor subjective well-being perempuan dewasa muda?

\section{METODE PENELITIAN}

Partisipan dalam penelitian ini berjumlah 500 partisipan, dengan kriteria perempuan dewasa muda awal (usia 20 - 28 tahun), minimal pendidikan terakhir SMA/sederajat, dan berdomisili di Jabodetabek. Peneliti menggunakan metode kuantitatif (regresi). Metode ini memusatkan perhatian pada fenomena yang aktual secara objektif. Variabel yang diukur akan menggambarkan fakta-fakta masalah yang diselidiki. Kemudian data statistik dan data diri yang diperoleh akan dianalisa menggunakan teori. Teknik pemilihan sampel yang digunakan adalah non-probability. Peneliti menggunakan jenis purposive sampling (sampel ditentukan berdasarkan karakteristik subjek). Peneliti menyebar kuesioner secara online menggunakan Google Forms, sehingga partisipan penelitian dapat menyatakan persetujuan pengisian (informed consent) dan mengisi kuesioner menggunakan gadget. Hal tersebut guna mempermudah partisipan dalam mengisi kuesioner. Penelitian ini menggunakan tiga alat ukur, sebagai berikut:

Rosenberg Self-Esteem Scale (RSES). Penelitian ini menggunakan alat ukur Rosenberg Self-Esteem Scale (RSES) yang dikembangkan oleh Moris Rosenberg pada tahun 1965. Alat ukur ini telah digunakan oleh Ritung (2018, tesis yang berjudul "Penerapan Art Therapy dalam Meningkatkan Self-Esteem pada Korban Kekerasan dalam Rumah Tangga"). Pada penelitian ini, RSES terdiri dari 10 butir pernyataan dengan 1 butir tidak valid setelah dilakukan uji reliabilitas, yakni butir 8 . Oleh sebab, butir 8 memiliki skor corrected item-total correlation di bawah 0,200 . RSES memiliki skala 0 - 3 untuk masing-masing jawaban, sehingga rentang skor yang dimiliki secara keseluruhan (termasuk 5 butir negatif yang telah dibalik perhitungannya) adalah $0-30$ dan memiliki reliabilitas yang tinggi, yaitu sebesar 0,820, menunjukkan bahwa kesembilan butir yang valid dapat digunakan sebagai instrumen alat ukur self-esteem pada penelitian ini. RSES memiliki empat pilihan jawaban, yaitu Sangat Tidak Setuju (STS), Tidak Setuju (ST), Setuju (S), dan Sangat Setuju (SS). RSES pada penelitian ini menggunakan lima norma kategori yang dihitung dari mean empiric sampel penelitian, yang pada penelitian ini berjumlah 500 sampel dan hasil pengkategoriannya dilihat dari total butir valid (Widhiarso, 2010), yakni Sangat Rendah $(X \leq 12)$, Rendah $(12<X \leq 14)$, Sedang $(14<X \leq 16)$, Tinggi $(16<X \leq 20)$, dan Sangat Tinggi $(20<X)$. 
Heartland Forgiveness Scale (HFS). Independent variable lainnya dalam penelitian ini menggunakan alat ukur Heartland Forgiveness Scale (HFS). Peneliti hanya menggunakan sub-skala Forgiveness of Self pada alat ukur HFS. HFS telah diterjemahkan oleh dosen Fakultas Psikologi Universitas Indonesia yang bernama Julia Suleeman dan Zivana Sabili pada tahun 2016 melalui proses backtranslation. Selain itu, skala alat ukur ini juga telah diadaptasi menjadi empat pilihan jawaban, karena disesuaikan dengan kecenderungan masyarakat Indonesia yang kerap kali menjawab netral pada skala ganjil. HFS merupakan alat ukur milik Thompson, et al. (2005) yang terdiri dari 18 butir. HFS memiliki tiga sub-skala, yaitu Forgiveness of Self, Forgiveness of Others, dan Forgiveness of Situation. HFS yang sudah diterjemahkan memiliki 18 butir dan empat pilihan jawaban, yaitu Sangat Tidak Setuju (STS), Tidak Setuju (ST), Setuju (S), dan Sangat Setuju (SS), dengan rentang skor $0-18$ pada tiap dimensi. Pada penelitian ini, peneliti hanya menggunakan dimensi self-forgiveness yang berjumlah 6 butir dengan 1 butir tidak valid setelah dilakukan uji reliabilitas, yakni butir 2. Oleh sebab, butir 2 memiliki skor corrected item-total correlation di bawah 0,200 . Hasil uji reliabilitas untuk HFS dimensi self-forgiveness menghasilkan skor yang dapat diterima, yakni 0,610. HFS pada penelitian ini menggunakan lima norma kategori yang dihitung dari mean empiric sampel penelitian, yang pada penelitian ini berjumlah 500 sampel dan hasil pengkategoriannya dilihat dari total butir valid (Widhiarso, 2010), yakni Sangat Rendah ( $X \leq 6)$, Rendah $(6<X \leq 7)$, Sedang $(7<X \leq 8)$, Tinggi $(8<X$ $\leq 11)$, dan Sangat Tinggi $(11<\mathrm{X})$.

Oxford Happiness Questionnaire (OHQ). Selain alat ukur RSES dan HFS, penelitian ini menggunakan alat ukur Oxford Happiness Questionnaire (OHQ) untuk mengukur subjective well-being individu. Alat ukur ini telah digunakan oleh Putri (2017, tesis yang berjudul "Penerapan Positive Psychology Interventions dalam Meningkatkan Subjective Well-Being pada Individu dengan Disabilitas Fisik karena Kecelakaan"). OHQ dikembangkan oleh psikolog di Universitas Oxford, yakni Michael Argyle dan Peter Hills pada tahun 2002. Alat ukur ini digunakan dalam penelitian, karena mampu mengukur subjective well-being individu yang sesuai dengan definisi subjective well-being atau happiness yang dikemukakan oleh Diener, yakni adanya evaluasi afektif yaitu tingginya afek positif dan rendahnya afek negatif, serta evaluasi kognitif yakni kepuasan terhadap hidupnya (Diener, Oishi, \& Tay, 2018). Selain itu, OHQ juga memiliki skor reliabilitas yang tinggi, yakni 0,932, yang memberi arti bahwa OHQ dapat mengukur subjective well-being dengan baik dan memiliki eror pengukuran yang kecil. OHQ terdiri dari 29 butir pernyataan dengan 1 butir tidak valid setelah dilakukan uji reliabilitas, yakni butir 21. Oleh sebab, butir 21 memiliki skor corrected itemtotal correlation di bawah 0,200. OHQ menggunakan 6 point-scale (mulai dari sangat tidak setuju hingga sangat setuju). Total skor untuk skala ini diperoleh dengan menjumlahkan skor pada setiap butir, termasuk 12 butir yang telah dibalik penghitungannya, kemudian dibagi dengan jumlah skor butir yakni 29 hingga diperoleh skor yang dapat merepresentasikan tingkat subjective well-being individu. Berikut penjabaran dari skor interpretasi alat ukur OHQ:

Tabel 1 Penjelasan Skor dan Interpretasi Alat Ukur OHQ

\begin{tabular}{cl}
\hline Skala Skor & \multicolumn{1}{c}{ Interpretasi Skor } \\
\hline $1-2$ & $\begin{array}{l}\text { Not Happy. Individu dalam kategori ini tergolong tidak bahagia. Skor ini mengindikasikan } \\
\text { individu mengalami depresi. }\end{array}$ \\
$2-3$ & $\begin{array}{l}\text { Somewhat Unhappy. Individu dalam kategori ini tergolong cukup merasa tidak bahgia. } \\
\text { Not Particularly Happy or Unhappy. Individu dalam kategori ini tergolong tidak begitu bahagia } \\
\text { sekaligus tidak begitu tidak bahagia, dapat dikatakan biasa saja. }\end{array}$ \\
& $\begin{array}{l}\text { Somewhat Happy or Moderately Happy. Individu dalam kategori ini tergolong cukup merasa } \\
\text { puas terhadap hidupnya. Skor rata-rata seseorang. }\end{array}$ \\
$4-5$ & $\begin{array}{l}\text { Rather Happy; Pretty Happy. Individu dalam kategori ini tergolong cukup merasa bahagia. } \\
5-6\end{array}$ \\
Very Happy. Individu dalam kategori ini tergolong merasa sangat bahagia. \\
Too Happy. Individu dalam kategori ini tergolong sangat bahagia dalam memandang \\
kehidupannya.
\end{tabular}




\section{HASIL DAN PEMBAHASAN}

\section{Hasil}

Seluruh data penelitian diolah dengan teknik explore (descriptive statistic) dan analyze (regression) menggunakan SPSS Statistic versi 24. Berikut gambaran ketiga variabel penelitian ini.

Self-esteem. Nilai mean empirik self-esteem adalah 17,2. Berdasarkan norma alat ukur, kategori tinggi berada pada rentang skor $16<X \leq 20$, sehingga alat ukur ini menunjukkan bahwa secara umum self-esteem perempuan dewasa muda awal (usia 20 - 28 tahun) di Jabodetabek, dengan minimal pendidikan SMA/ sederajat, tergolong tinggi. Jumlah partisipan pada kategori self-esteem tinggi berjumlah 232 dari 500 partisipan (dapat dilihat pada Tabel 3). Selain itu, butir 10 ("saya menanamkan sifat positif terhadap diri saya sendiri") merupakan butir yang memiliki nilai mean tertinggi, yakni 2,22 (dapat dilihat pada Gambar 1). Hal ini menunjukkan penanaman sifat positif pada diri merupakan sebagian besar cara partisipan dalam menghargai diri mereka. Berikut tabel gambaran variabel self-esteem pada perempuan dewasa muda awal:

Tabel 2 Kategorisasi Variabel Self-Esteem

\begin{tabular}{|c|c|c|c|c|c|c|}
\hline \multirow[b]{2}{*}{ Self-Esteem } & \multicolumn{5}{|c|}{ Kategori } & \multirow[b]{2}{*}{$\begin{array}{c}\text { Total } \\
\text { Partisipan }\end{array}$} \\
\hline & $\begin{array}{c}\text { Sangat } \\
\text { Rendah } \\
(X \leq 12)\end{array}$ & $\begin{array}{c}\text { Rendah } \\
(12<X \leq \\
14)\end{array}$ & $\begin{array}{c}\text { Sedang } \\
(14<X \leq \\
16)\end{array}$ & $\begin{array}{c}\text { Tinggi } \\
(16<X \leq \\
20)\end{array}$ & $\begin{array}{c}\text { Sangat } \\
\text { Tinggi } \\
(20<X)\end{array}$ & \\
\hline $\begin{array}{l}\text { Jumlah } \\
\text { Partisipan }\end{array}$ & 41 & 66 & 81 & 232 & 80 & 500 \\
\hline Persentase & $8,2 \%$ & $13,2 \%$ & $16,2 \%$ & $46,4 \%$ & $16 \%$ & $100 \%$ \\
\hline
\end{tabular}

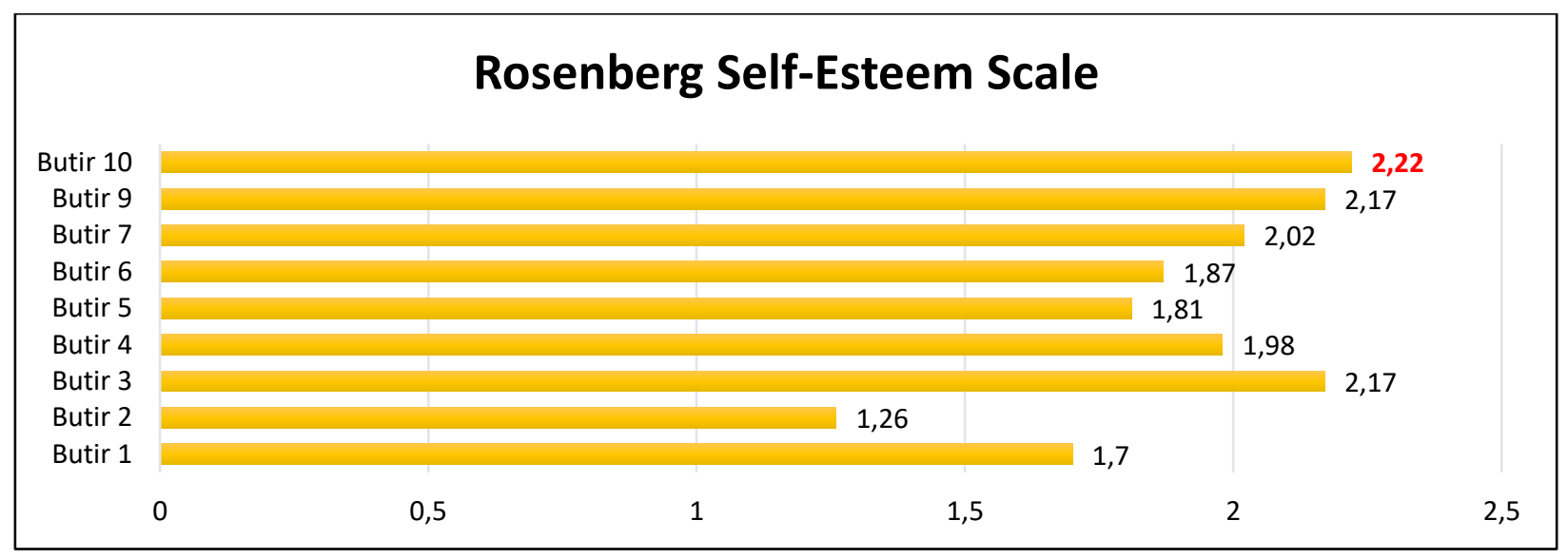

Gambar 1. Mean Butir-Butir Alat Ukur Self-Esteem.

Lebih lanjut, berdasarkan tahun kelahiran, tahun 1992 memiliki skor mean yang paling tinggi (mean = 1,83). Sedangkan, tahun 1998 memiliki skor mean paling rendah (mean =1,56). Hal tersebut menunjukkan bahwa perempuan kelahiran 1992 memiliki tingkat self-esteem yang paling tinggi dan perempuan kelahiran 1998 memiliki tingkat self-esteem yang paling rendah. Berdasarkan pendidikan terakhir, pendidikan SMA/ sederajat dan D3 memiliki skor mean yang paling rendah, yakni 1,65. Sedangkan, S2 memiliki skor mean yang paling tinggi (mean $=1,90)$. Hal tersebut menunjukkan bahwa perempuan dengan pendidikan terakhir SMA/ sederajat dan D3 memiliki tingkat self-esteem yang paling rendah dan perempuan dengan pendidikan terakhir S2 memiliki tingkat self-esteem yang paling tinggi. Berdasarkan daerah tempat tinggal, wilayah Bogor memiliki skor mean yang paling tinggi, yakni 1,79. Sedangkan, wilayah Bekasi memiliki skor mean yang paling rendah, yakni 1,63. Hal tersebut menunjukkan bahwa perempuan yang berdomisili di wilayah Bogor memiliki tingkat self-esteem yang paling tinggi dan perempuan yang berdomisili di wilayah Bekasi memiliki tingkat self-esteem yang paling rendah.

Self-forgiveness. Nilai mean empirik self-forgiveness adalah 8,8. Berdasarkan norma alat ukur, kategori tinggi berada pada rentang skor $8<X \leq 11$, sehingga alat ukur ini menunjukkan bahwa secara umum selfforgiveness perempuan dewasa muda awal (usia 20 - 28 tahun) di Jabodetabek, dengan minimal pendidikan 
SMA/ sederajat, tergolong tinggi. Jumlah partisipan pada kategori self-forgiveness tinggi berjumlah 249 dari 500 partisipan (dapat dilihat pada Tabel 5). Selain itu, butir 6 ("seiring dengan berjalannya waktu, saya lebih memaklumi diri sendiri untuk kesalahan-kesalahan yang saya sudah lakukan") merupakan butir yang memiliki nilai mean tertinggi, yakni 1,92 (dapat dilihat pada Gambar 2). Hal ini menunjukkan dengan cara memaklumi diri sendiri, sebagian besar partisipan mampu menerima bahwa setiap manusia tidak sempurna dan dapat berbuat salah. Berikut tabel gambaran variabel self-forgiveness pada perempuan dewasa muda awal:

Tabel 3 Kategorisasi Variabel Self-Forgiveness

\begin{tabular}{lcccccc}
\hline $\begin{array}{l}\text { Self- } \\
\text { Forgiveness }\end{array}$ & $\begin{array}{c}\text { Sangat } \\
\text { Rendah } \\
(\mathrm{X} \leq 6)\end{array}$ & $\begin{array}{c}\text { Rendah } \\
(6<\mathrm{X} \leq 7)\end{array}$ & $\begin{array}{c}\text { Sedang } \\
(7<\mathrm{X} \leq 8)\end{array}$ & $\begin{array}{c}\text { Tinggi } \\
(8<\mathrm{X} \leq 11)\end{array}$ & $\begin{array}{c}\text { Sangat } \\
\text { Tinggi } \\
(11<\mathrm{X})\end{array}$ & $\begin{array}{c}\text { Total } \\
\text { Partisipan }\end{array}$ \\
\hline $\begin{array}{l}\text { Jumlah } \\
\text { Partisipan }\end{array}$ & 56 & 64 & 100 & 249 & 31 & 500 \\
\hline Persentase & $11,2 \%$ & $12,8 \%$ & $20 \%$ & $49,8 \%$ & $6,2 \%$ & $100 \%$ \\
\hline
\end{tabular}

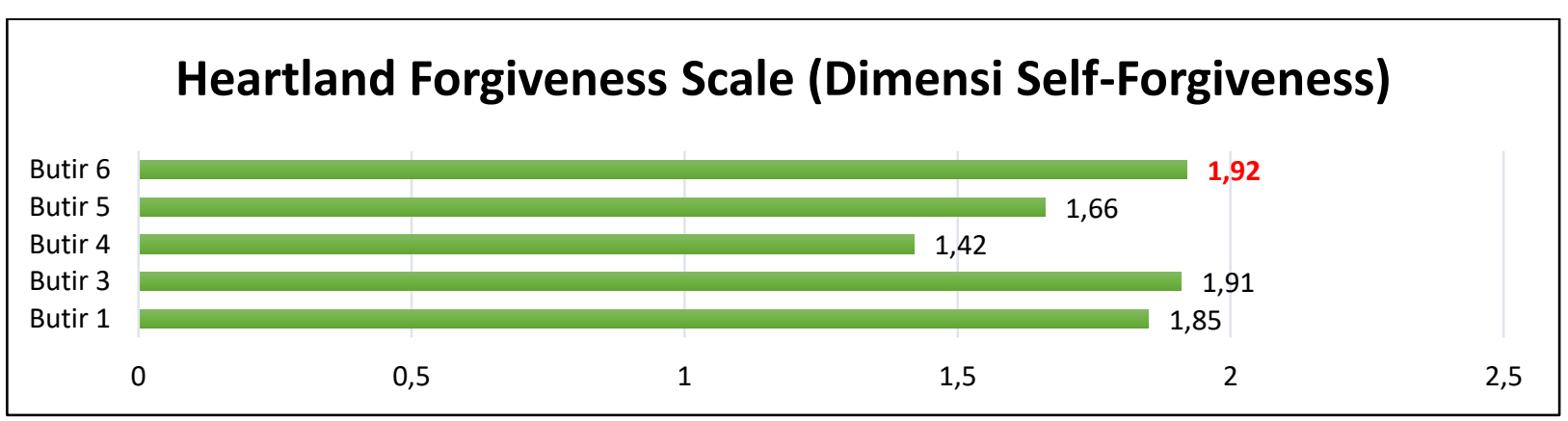

Gambar 2. Mean Butir-Butir Alat Ukur Self-Forgiveness.

Lebih lanjut, berdasarkan tahun kelahiran, tahun 1992 memiliki skor mean paling tinggi (mean =1,58). Sedangkan, tahun 1998 memiliki skor mean paling rendah, yakni 1,36. Hal tersebut menunjukkan bahwa perempuan kelahiran tahun 1992 memiliki tingkat self-forgiveness yang paling tinggi. Sedangkan, perempuan kelahiran tahun 1998 memiliki tingkat self-esteem paling rendah. Berdasarkan pendidikan terakhir, pendidikan D3 memiliki skor mean paling rendah (mean $=1,37)$. Sedangkan, pendidikan S2 memiliki skor mean yang paling tinggi (mean $=1,49$ ). Hal tersebut menunjukkan bahwa perempuan dengan pendidikan terakhir D3 memiliki tingkat self-forgiveness yang paling rendah dan perempuan dengan pendidikan terakhir S2 memiliki tingkat self-forgiveness yang paling tinggi. Berdasarkan wilayah tempat tinggal, wilayah Jakarta memiliki skor mean paling tinggi, yakni 1,48. Sedangkan, wilayah Bogor memiliki skor mean yang paling rendah, yakni 1,40. Hal tersebut menunjukkan bahwa, perempuan yang berdomisili di wilayah Jakarta memiliki tingkat self-forgiveness yang paling tinggi dan perempuan yang berdomisili di wilayah Bogor memiliki tingkat self-forgiveness yang paling rendah.

Subjective well-being. Nilai mean empirik subjective well-being adalah 4,1. Berdasarkan norma alat ukur, kategori rather happy (cukup merasa bahagia) berada pada rentang skor $4-5$, sehingga alat ukur ini menunjukkan bahwa secara umum perempuan dewasa muda awal (usia 20 - 28 tahun) di Jabodetabek, dengan minimal pendidikan SMA/ sederajat, tergolong cukup merasa bahagia. Jumlah partisipan pada kategori self-forgiveness tinggi berjumlah 264 dari 500 partisipan (dapat dilihat pada Tabel 7). Selain itu, butir 7 ("saya menemukan banyak hal yang menyenangkan dalam hidup") merupakan butir yang memiliki nilai mean tertinggi, yakni 4,78 (dapat dilihat pada Gambar 3). Hal ini menunjukkan sebagian besar partisipan melihat berbagai hal positif dalam hidupnya yang membuat mereka merasa cukup puas dan bahagia akan kehidupannya. Berikut tabel gambaran variabel subjective well-being pada perempuan dewasa muda awal: 
Tabel 4 Kategorisasi Variabel Subjective Well-Being (SWB)

\begin{tabular}{|c|c|c|c|c|c|c|c|}
\hline \multirow[b]{2}{*}{ SWB } & \multicolumn{7}{|c|}{ Kategori } \\
\hline & $\begin{array}{c}\text { Not } \\
\text { Happy } \\
(1-2)\end{array}$ & $\begin{array}{c}\text { Somewhat } \\
\text { Unhappy (2-3) }\end{array}$ & $\begin{array}{c}\text { Not } \\
\text { Particularly } \\
\text { Happy or } \\
\text { Unhappy } \\
\text { (3-4) }\end{array}$ & $\begin{array}{c}\text { Somewhat } \\
\text { Happy } \\
\text { (4) }\end{array}$ & $\begin{array}{c}\text { Rather } \\
\text { Happy } \\
(4-5)\end{array}$ & $\begin{array}{c}\text { Very } \\
\text { Happy } \\
(5-6)\end{array}$ & $\begin{array}{c}\text { Too } \\
\text { Happy } \\
(>6)\end{array}$ \\
\hline $\begin{array}{l}\text { Total } \\
(500)\end{array}$ & 0 & 20 & 184 & 7 & 264 & 25 & 0 \\
\hline$(\%)$ & $0 \%$ & $4 \%$ & $36,8 \%$ & $1,4 \%$ & $52,8 \%$ & $5 \%$ & $0 \%$ \\
\hline
\end{tabular}

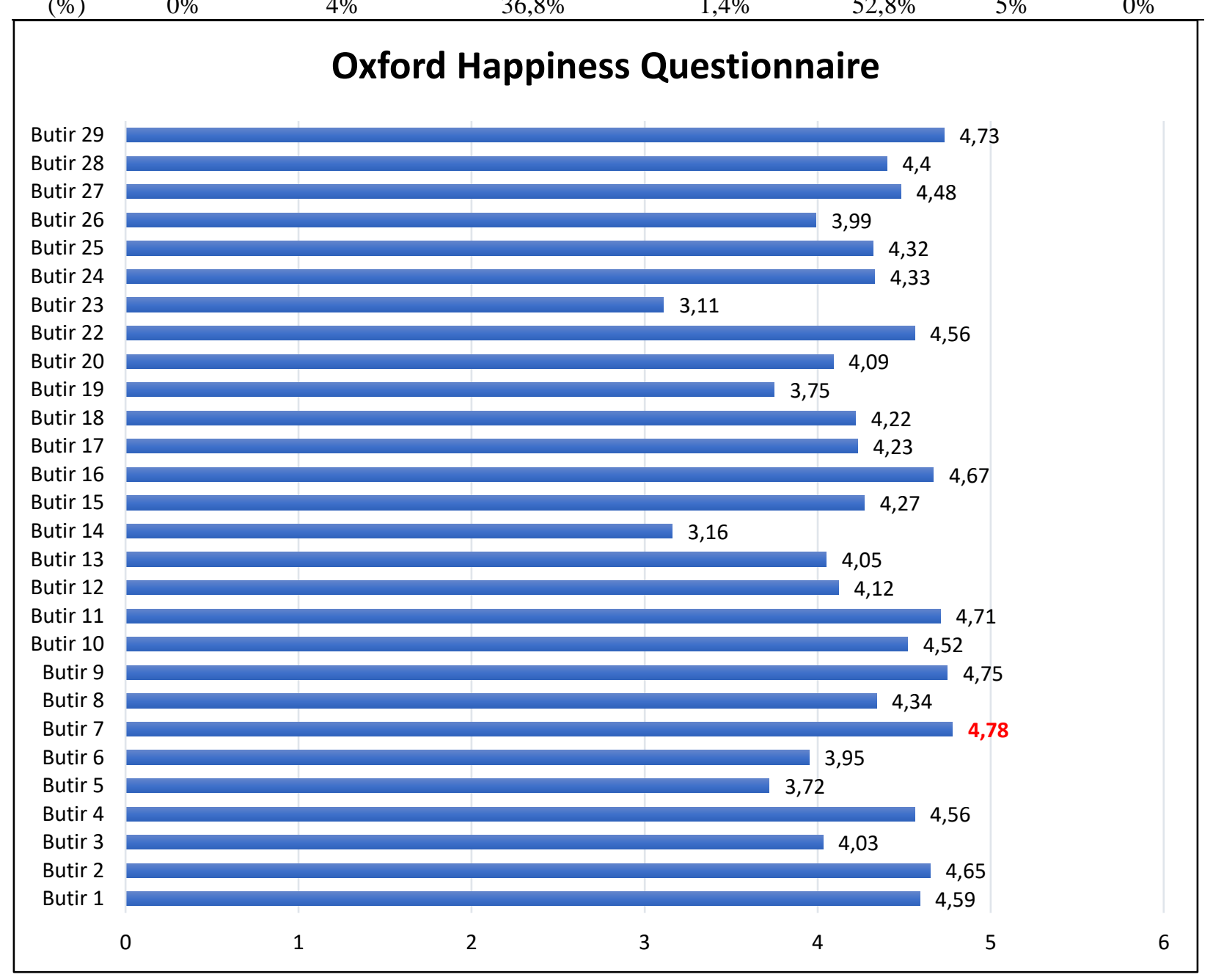

Gambar 3. Mean Butir-Butir Alat Ukur Subjective Well-Being.

Lebih lanjut, berdasarkan tahun kelahiran, tahun 1992 memiliki skor mean paling tinggi (mean = 4,25). Sedangkan, tahun 1998 memiliki skor mean paling rendah (mean =3,83). Hal tersebut menunjukkan bahwa perempuan kelahiran tahun 1992 memiliki tingkat subjective well-being yang paling tinggi dan perempuan kelahiran tahun 1998 memiliki tingkat subjective well-being yang paling rendah. Berdasarkan pendidikan terakhir, pendidikan SMA/ sederajat memiliki skor mean paling rendah, yakni 3,99. Sedangkan, pendidikan S2 memiliki skor mean paling tinggi, yakni 4,30. Hal tersebut menunjukkan bahwa perempuan dengan pendidikan terakhir SMA/ sederajat memiliki tingkat subjective well-being yang paling rendah dan perempuan dengan pendidikan terakhir S2 memiliki tingkat subjective well-being yang paling tinggi. Berdasarkan wilayah tempat tinggal, wilayah Bogor memiliki skor mean yang paling tinggi, yakni 4,21. Sedangkan, wilayah Bekasi memiliki skor mean yang paling rendah, yakni 4,02. Hal tersebut menunjukkan bahwa perepuan yang berdomisili di wilayah Bogor memiliki tingkat subjective well-being yang paling tinggi dan perempuan yang berdomisili di wilayah Bekasi memiliki tingkat subjective well-being yang paling rendah. 
Hasil uji korelasi. Peneliti melakukan uji korelasi pearson untuk mengetahui hubungan antara variabelvariabel pada penelitian ini. Hasil uji korelasi terangkum pada tabel berikut:

Tabel 5

Hubungan antara Independent Variable dan Dependent Variable

\begin{tabular}{lc}
\hline \multicolumn{1}{c}{ Independent Variable (IV) } & Subjective Well-Being (DV) \\
\hline Self-Esteem & $0,725^{* *}$ \\
Self-Forgiveness & $0,423^{* *}$ \\
\hline$* *=$ Nilai korelasi signifikansi pada tingkat 0,01 (2-tailed)
\end{tabular}

** = Nilai korelasi signifikansi pada tingkat 0,01 (2-tailed)

Berdasarkan Tabel 8 dapat dilihat bahwa kedua independent variable (self-esteem dan self-forgiveness) memiliki korelasi positif yang signifikan terhadap dependent variable, yakni subjective well-being. Hasil ini menggambarkan bahwa gambaran self-esteem dan self-forgiveness perempuan dewasa muda awal (usia 20 - 28 tahun) di Jabodetabek, dengan minimal pendidikan SMA/ sederajat, memiliki hubungan dengan gambaran subjective well-being mereka. Lebih lanjut, pada penelitian yang memiliki independent variable lebih dari satu, variabel-variabel tersebut perlu dilakukan uji korelasi yang menyatakan hubungan keduanya $<0,8$. Oleh sebab pertimbangan tersebut, setelah hubungan self-esteem dan self-forgiveness diuji, memperoleh hasil 0,444. Hal tersebut menunjukkan kedua variabel tersebut mampu berperan sebagai independent variable pada penelitian ini.

Hasil uji hipotesis. Dalam menghitung regresi peran self-esteem dan self-forgiveness sebagai prediktor subjective well-being secara bersama-sama, peneliti menggunakan metode uji regresi linier berganda. Hasil pengujian dapat dilihat dari tabel berikut:

Tabel 6 Tabel Uji Hipotesis: Peran Self-Esteem dan Self-Forgiveness sebagai Prediktor Subjective Well-

\begin{tabular}{llcc}
\multicolumn{4}{c}{ Being secara Bersama-sama } \\
\hline \multicolumn{1}{c}{ Prediktor } & $\mathrm{R}^{2}$ & $\mathrm{~F}$ & Sig. \\
\hline $\begin{array}{l}\text { (Constant) } \\
\begin{array}{l}\text { Self-Esteem dan Self- } \\
\text { Forgiveness }\end{array}\end{array}$ & 0,538 & 289,504 & 0,000 \\
\hline
\end{tabular}

Hasil uji regresi menunjukkan bahwa self-esteem dan self-forgiveness berperan secara signifikan sebagai prediktor subjective well-being secara bersama-sama $(\mathrm{F}=289,504 ; \mathrm{p}<0,05)$. Self-esteem dan selfforgiveness memberikan kontribusi secara bersama-sama $\left(\mathrm{R}^{2}=0,538\right)$ sebesar $53,8 \%$ pada gambaran subjective well-being perempuan dewasa muda awal, sedangkan lainnya dipengaruhi oleh faktor lain di luar dari variabel yang diteliti.

Hasil analisis tambahan. Dalam menghitung regresi peran self-esteem sebagai prediktor subjective wellbeing, peneliti menggunakan metode uji regresi linier berganda. Hasil pengujian dapat dilihat dari tabel berikut:

Tabel 7 Tabel Analisis Tambahan: Peran Self-Esteem sebagai Prediktor Subjective Well-Being

\begin{tabular}{cccc}
\hline \multicolumn{1}{c}{ Prediktor } & $\mathrm{R}^{2}$ & $\mathrm{~F}$ & Sig. \\
\hline (Constant) & 0,525 & 551,457 & 0,000 \\
\hline Self-Esteem & & & \\
\hline
\end{tabular}

Hasil uji regresi menunjukkan bahwa self-esteem berperan secara signifikan sebagai prediktor subjective well-being $(\mathrm{F}=551,457$; $\mathrm{p}<0,05)$. Self-esteem memberikan kontribusi $\left(\mathrm{R}^{2}=0,525\right)$ sebesar $52,5 \%$ pada gambaran subjective well-being perempuan dewasa muda awal, sedangkan lainnya dipengaruhi oleh faktor lain di luar dari variabel yang diteliti.

Lebih lanjut, dalam menghitung regresi peran self-forgiveness sebagai prediktor subjective well-being, peneliti menggunakan metode uji regresi linier berganda. Hasil pengujian dapat dilihat dari tabel berikut: 
Tabel 8 Tabel Analisis Tambahan: Peran Self-Forgiveness sebagai Prediktor Subjective Well-Being

\begin{tabular}{cccc}
\hline \multicolumn{1}{c}{ Prediktor } & $\mathrm{R}^{2}$ & $\mathrm{~F}$ & Sig. \\
\hline $\begin{array}{l}\text { (Constant) } \\
\text { Self-Forgiveness }\end{array}$ & 0,179 & 108,457 & 0,000 \\
\hline
\end{tabular}

Hasil uji regresi menunjukkan bahwa self-forgiveness berperan secara signifikan sebagai prediktor subjective well-being $(F=108,457 ; p<0,05)$. Self-forgiveness memberikan kontribusi $\left(R^{2}=0,179\right)$ sebesar $17,9 \%$ pada gambaran subjective well-being perempuan dewasa muda awal, sedangkan lainnya dipengaruhi oleh faktor lain di luar dari variabel yang diteliti.

\section{Pembahasan}

Penelitian yang dilakukan pada 500 partisipan, yakni perempuan dewasa muda awal (usia 20 - 28 tahun), menunjukkan bahwa self-esteem dan self-forgiveness berperan sebagai prediktor subjective well-being. Self-esteem berperan sebesar 52,5\% terhadap subjective well-being dan self-forgiveness berperan sebesar 17,9\%. Kemudian, apabila keduanya digabungkan (self-esteem dan self-forgiveness), keduanya berperan sebesar 53,8\% terhadap subjective well-being. Hasil penelitian ini menunjukkan self-esteem memiliki peran lebih besar terhadap subjective well-being dibandingkan dengan self-forgiveness, dan mampu mempengaruhi peran self-forgiveness ketika digabungkan. Sehingga, dapat dikatakan bahwa self-esteem memiliki pengaruh yang kuat terhadap subjective well-being dan merupakan variabel yang tepat dalam memprediksi subjective well-being individu. Namun, penelitian yang dilakukan oleh Eddington dan Shuman (2008) menunjukkan hasil yang berbeda, yakni bahwa self-esteem berhubungan kuat secara positif hanya di budaya barat. Hubungan yang kuat antara self-esteem dan subjective well-being tidak ditemukan secara konsisten di beberapa negara, terutama di negara-negara penganut sistim kolektif, seperti di Cina. Menurut Eddington dan Shuman (2008), di negara-negara tersebut, otonomi dan tuntutan pribadi dianggap tidak lebih penting daripada kesatuan keluarga dan sosial, sehingga self-esteem menjadi prediktor subjective well-being yang kurang penting. Namun, beberapa tahun setelahnya, penelitian oleh Quevedo \& Abella (2011) dan Lu et al. (2015), dalam Yao et al. (2017) yang dilakukan di Cina, memperoleh hasil yang mampu mendukung hasil penelitian peneliti, yakni self-esteem di negara kolektif merupakan variabel yang stabil dalam menggambarkan subjective well-being dan self-esteem juga mampu mempengaruhi subjective wellbeing. Hasil penelitian peneliti berlaku di wilayah Jabodetabek, yakni wilayah yang berada di negara dengan sistim kolektif, Indonesia. Oleh sebab Indonesia merupakan negara budaya timur dan termasuk ke dalam negara yang menganut sistim kolektif, sehingga hasil dari kedua penelitian yang dilakukan di Cina dapat dikatakan sejalan dengan hasil penelitian peneliti.

Kuatnya peran self-esteem terhadap subjective well-being juga didukung oleh penjelasan Diener, Oishi, \& Tay (2018) bahwa subjective well-being merupakan evaluasi subjektif individu mengenai kehidupan termasuk konsep-konsep seperti kepuasan hidup, emosi menyenangkan, fulfilment, kepuasan terhadap pernikahan dan pekerjaan, serta rendahnya tingkat emosi yang tidak menyenangkan. Selain itu, subjective well-being didefinisikan juga sebagai evaluasi kognitif dan afektif individu tentang hidupnya. Evaluasi ini meliputi penilaian emosional terhadap berbagai kejadian yang dialami yang sejalan dengan penilaian kognitif terhadap kepuasan dan pemenuhan kebutuhan. Individu dideskripsikan mempunyai subjective well-being yang tinggi apabila ia menilai kepuasan hidupnya tinggi, dan merasakan afek positif lebih sering dibandingkan afek negatif (Diener etal., 2018). Penjelasan tersebut menunjukkan bahwa subjective wellbeing berkaitan dengan penilaian positif individu akan kehidupannya. Hal ini sejalan dengan pengertian self-esteem menurut Rosenberg (1965), dalam Abdel-Khalek (2016) dan menurut Santrock (dalam Kamila \& Mukhlis, 2013), yakni sebuah penilaian umum tentang diri sendiri yang berkaitan dengan kemampuan diri, memiliki sesuatu yang bernilai, dan memiliki nilai dalam pandangan orang lain, serta merupakan salah satu aspek kepribadian yang mempunyai peran penting dan berpengaruh terhadap sikap dan perilaku individu. Selain itu, National Association for Mental Health (2016) juga menyatakan bahwa self-esteem mengarah pada keyakinan diri, bagaimana individu memandang dirinya, kemampuan apa yang dimiliki dirinya, dan berbagai hal positif dan negatif mengenai dirinya dan harapan di masa depan. Berdasakan penjelasan di atas, terlihat bahwa self-esteem dan subjective well-being merupakan dua aspek penting penilaian diri dalam kehidupan. Keduanya memiliki arti yang sejalan dan saling berkaitan, sehingga mampu mendasari besar peranan self-esteem sebagai prediktor subjective well-being. 
Meskipun dalam penelitian ini self-forgiveness memiliki peran yang lebih kecil dari self-esteem, namun self-forgiveness tetap berperan sebagai prediktor subjective well-being. Hal ini mampu mendukung pendapat Thompson, et al. (2005) dan penelitian Safaria et al. (dalam Yao et al., 2017) yang memperoleh hasil, bahwa self-forgiveness dan life satisfaction (komponen dari subjective well-being) saling berhubungan secara signifikan. Selain itu, penelitian yang dilakukan oleh Gull (2013), dalam Yao, et al. (2017) juga menjelaskan bahwa sikap tidak memaafkan memicu perasaan negatif dan stres psikologis. Sebaliknya, sikap memaafkan menimbulkan perasaan positif. Hal ini mendukung penelitian yang dilakukan oleh Maltby et al. (dalam Yao et al. 2017) yang menjelaskan bahwa self-forgiveness memiliki hubungan yang negatif dengan depresi dan kecemasan, serta dapat membantu individu meningkatkan quality of life mereka. Selain itu, Yao et al. (2017) menjelaskan subjective well-being juga merupakan salah satu aspek penting dalam quality of life dan kesehatan mental individu. Berdasarkan berbagai hasil penelitian tersebut dapat menjadi pendukung hasil penelitian ini, yakni bahwa self-forgiveness merupakan variabel yang dapat dijadikan prediktor subjective well-being, karena self-forgiveness berhubungan secara signifikan dengan variabel-variabel positif yang dapat mendasari penilaian positif individu akan hidupnya.

Penjelasan di atas jelas menyatakan dasar self-forgiveness memiliki peran sebagai prediktor subjective wellbeing, namun yang menarik dari hasil penelitian ini adalah hal apa yang menyebabkan peran selfforgiveness lebih kecil dari peran self-esteem. Berdasarkan faktor yang mempengaruhi individu dalam memaafkan, McCullough et al. (1997) memaparkan kemampuan individu dalam memaafkan cenderung berkaitan dengan situasi atau pihak lain yang berbuat salah di luar dari individu yang bersangkutan. Hal ini memperjelas bahwa, meskipun self-forgiveness berhubungan secara signifikan dengan subjective wellbeing dan terbukti menjadi prediktor subjective well-being, namun self-forgiveness tidak menjadi komponen terkuat individu ketika mengaplikasikan forgiveness dalam hidupnya. Self-forgiveness merupakan kemampuan individu dalam mengabaikan rasa benci akan diri sendiri setelah berbuat kesalahan, dan membangun rasa cinta terhadap diri. Kemampuan tersebut ditandai dengan sikap positif terhadap kesalahan dengan tidak menghukum diri sendiri (Carpenter, et al., 2016). Rasa cinta terhadap diri berkaitan dengan penilaian positif akan diri sendiri. Individu yang mampu mengaplikasikan self-forgiveness menunjukkan kesadaran bahwa manusia tidak sempurna dan ketidak-sempurnaan tersebut yang dapat menjadi dasar manusia tidak selamanya mampu mencapai ideal self (Jacinto \& Edwards, 2011). Selfforgiveness dapat diaplikasikan saat individu mampu mensykuri kekurangannya seperti ia mensyukuri kelebihannya. Oleh karenanya, individu perlu menyadari bahwa setiap manusia tidak sempurna dan sebagian besar dari mereka berusaha untuk menjadi pribadi terbaik semampu mereka (Jacinto \& Edwards, 2011). Berdasarkan penjelasan mengenai self-forgiveness, pada dasarnya self-forgiveness lebih fokus pada kemampuan individu dalam merefleksi dan menerima kekurangan diri. Sedangkan, faktor-faktor yang mendorong individu untuk mampu memaafkan cenderung mengarah pada orang lain dan situasi. Hal ini mendasari asumsi peneliti bahwa saat terjadi kondisi yang tidak menyenangkan, individu cenderung fokus pada situasi atau pihak lain yang berkaitan dengan kondisi tidak menyenangkan, bagaimana situasi tersebut dapat terjadi atau kesalahan apa dan seberapa besar kesalahan yang orang lain perbuat, ketimbang melakukan refleksi dan introspeksi diri. Oleh sebab itu, jelas bahwa self-forgiveness memiliki peran sebagai prediktor yang lebih kecil dari self-esteem terhadap subjective well-being.

Apabila dirangkum secara keseluruhan berdasarkan teori dan berbagai hasil penelitian sebelumnya, subjective well-being merupakan gambaran kehidupan individu, yang dapat dilihat dari kualitas, tingkat kebahagiaan, dan tingkat kepuasan pribadi. Hal tersebut hanya mampu dinilai oleh individu yang bersangkutan. Penilaian pribadi dapat dilakukan dengan bagaimana individu memandang dirinya, menerima diri, baik menerima kelebihan dan kekurangannya, dan bagaimana individu memperlakukan dirinya. Myers dan Diener (1995), dalam Diener et al. (2018) menjelaskan bahwa individu yang memiliki tingkat subjective well-being yang tinggi, ditandai dengan adanya berbagai emosi positif dan kemampuan menghargai, serta memandang setiap peristiwa yang terjadi secara positif. Sedangkan, individu yang memiliki tingkat subjective well-being yang rendah memandang berbagai peristiwa yang terjadi dalam kehidupannya sebagai sesuatu yang tidak menyenangkan, dan menimbulkan berbagai hal negatif, seperti kemarahan, kecemasan, atau depresi. Peran self-esteem dan self-forgiveness sebagai prediktor yang signifikan terhadap subjective well-being dapat dilihat juga dari bagaimana subjective well-being individu 
terbentuk. Gambaran subjective well-being dapat terbentuk dari self-esteem yang merupakan gambaran penghargaan diri dan self-forgiveness yang merupakan gambaran penerimaan diri seutuhnya.

\section{KESIMPULAN DAN SARAN \\ Kesimpulan}

Penelitian dilakukan terhadap tiga variabel, yakni self-esteem, self-forgiveness sebagai variabel independent, dan subjective well-being sebagai variabel dependent. Berdasarkan analisis data yang telah dilakukan mengenai self-esteem dan self-forgiveness sebagai prediktor subjective well-being, maka dapat diperoleh kesimpulan bahwa self-esteem dan self-forgiveness berperan sebagai prediktor subjective wellbeing perempuan dewasa muda.

\section{Saran}

Jumlah partisipan dalam penelitian ini sudah terbilang cukup untuk mewakili populasi perempuan dewasa muda awal di Jabodetabek yang melebihi seratus ribu populasi (Badan Pusat Statistik, 2017). Namun, oleh karena peneliti menyebar kuesioner dengan menggunakan Google Forms, sehingga peneliti tidak dapat mengontrol jumlah partisipan secara merata berdasarkan tahun kelahiran, pendidikan terakhir, dan domisili partisipan. Bagi penelitian selanjutnya, jumlah partisipan dapat dikontrol secara merata agar memperoleh hasil yang lebih baik. Selain itu, pada penelitian selanjutnya dapat dilakukan intervensi dengan memperoleh sebagian dari partisipan yang memiliki self-esteem, self-forgiveness dan subjective well-being yang cenderung rendah, sehingga peneliti dapat mengontrol dan melakukan follow-up. Penelitian selanjutnya juga dapat dilakukan pada perempuan dewasa muda dengan rentang usia yang berbeda, misalnya dewasa muda tengah (28 - 33 tahun) dan dewasa muda akhir (33 - 40 tahun). Selain itu, penelitian selanjutnya dapat menguji dimensi forgiveness lainnya sebagai independent variable, yakni forgiveness of others dan forgiveness of the situation, untuk melihat seberapa besar peran keduanya terhadap subjective well-being.

\section{ACKNOWLEDGEMENT}

Peneliti mengucapkan kepada para partisipan yang telah dengan berbesar hati menyetujui dan mengisi kuesioner penelitian ini serta pihak-pihak yang lerlibat dalam penulisan ini baik secara langsung maupun tidak langsung, yang tidak disebut satu persatu.

\section{REFERENSI}

Abdel-Khalek, A. M. (2016). Introduction to the psychology of self-esteem. In Holloway, F. (Eds.). SelfEsteem: Perspectives, Influences, and Improvement Strategies (pp. 1-17). New York, USA: Nova Science Publishers, Inc.

Carpenter, T. P., Tignor, S. M., Tsang, J., \& Willet, A. (2016). Dispositional self-forgiveness, guilt- and shame-proneness, and the roles of motivational tendencies. Personality and Individual Differences, 98, 53-61

Devi, S. \& Jyotsana. (2018). Forgiveness, self-esteem, and subjective well-being among females across age. IOSR Journal of Humanities and Social Science (IOSR-JHSS), 23(7), 48-57. doi: 10.9790/08372301074857

Diener, E., Oishi, S., \& Tay, L. (2018). Introduction by the editors. In E. Diener, S. Oishi, \& L. Tay (Eds.), Handbook of well-being. Salt Lake City, UT: DEF Publishers.

Eddington, N. \& Shuman, R. (2008). Subjective well-being (happiness). San Diego, USA: Continuing Psychology Education, Inc.

Erol, R. Y. \& Orth, U. (2011). Self-esteem development from age 14 to 30 years: a longitudinal study. American Psychological Association, 101(3), 607-619

Jacinto, G. A. \& Edwards, B. L. (2011). Therapeutic stages of forgiveness and self-forgiveness. Journal of Human Behavior in the Social Environment, 21, 423-437. doi: 10.1080/15433714.2011.531215

Kamila, I. I. \& Mukhlis. (2013). Perbedaan harga diri (self-esteem) remaja ditinjau dari keberadaan ayah. Jurnal PsikologiI, 9(2), 100-112

Kementrian Kesehatan RI. (2017). Profil kesehatan indonesia: tahun 2016. Jakarta, INA: Kementrian Kesehatan Republik Indonesia.

McCullough, M. E., Worthington, E. L., Jr., \& Rachal, K. C. (1997). Interpersonal forgiving in close relationships. Journal of Personality and Social Psychology, 73(2), 321-336 
National Association for Mental Health. (2016). How to increase your self-esteem. London, UK: Mind.

Putri, N. R. (2017). Penerapan positive psychology interventions dalam meningkatkan subjective wellbeing pada individu dengan disabilitas fisik karena kecelakaan. Tesis.

Riset Kesehatan Dasar. (2013). Riset kesehatan dasar: Riskesdas 2013. Jakarta, INA: Riset Kesehatan Dasar.

Ritung, O. P. (2018). Penerapan art therapy dalam meningkatkan self-esteem pada korban kekerasan dalam rumah tangga. Tesis.

Thompson, L. Y., Synder, C. R., Hoffman, L., Michael, S. T., Rasmussen, H. N., ... Roberts, D. E. (2005). Dispositional forgiveness of self, others, and situations. Journal of Personality, 73(2), 313-359. doi: 10.1111/j.1467-6494.2005.00311.x

Widhiarso, W. (2011). Teori pengukuran. Yogyakarta, INA: Bahan Materi Fakultas Psikologi UGM.

Wirasto, R. T. (2012). Suicide prevention in indonesia: providing public advocacy. JMAJ, 55(1), 98-104

World Health Organization. (2017). Depression and other common mental disorders: global health estimates. Geneva, CH: WHO Document Production Services.

Yao, S., Chen, J., Yu, X., \& Sang, J. (2017). Mediator roles of interpersonal forgiveness and selfforgiveness between self-esteem and subjective well-being. CrossMark, 36, 585-592. doi: $10.1007 / \mathrm{s} 12144-016-9447-\mathrm{x}$ 